\title{
MANAJEMEN PENDIDIKAN MA'HAD ‘ALY DI LINGKUNGAN PONDOK PESANTREN Kasus Ma'had Aly Hasyim Asy'ari Tebuireng, Jombang
}

\author{
Mulyani Mudis Taruna \\ Peneliti Pendidikan Balai Penelitian dan Pengembangan Agama Semarang \\ Jl. Untung Suropati Kav. 70 Semarang \\ tarunamulyani@yahoo.com
}

\begin{abstract}
Abstrak
Judul penelitian ini adalah Implementasi Pendidikan Ma'had 'Aly Hasyim Asy'ari di Pondok Pesantren TebuirengJombang. Pendekatan yang digunakan dalam penelitian adalah pendekatan kualitatif. Hasil penelitian adalah 1) Ma'had 'Aly Hasyim Asy'ari menekankan pada kitab-kitab klasik dan berorientasi pada lahirnya generasi penerus Islam yang khairu ummah, tafaqquh fi ad-diin, 2) Model penyelenggaraan pendidikan Ma'had 'Aly Hasyim Asy'ari adalah perpaduan antara pendidikan pondok pesantren salafiyah dan perguruan tinggi, 3) Faktor pendukung dalam implementasi Pendidikan di Ma'had 'Aly Hasyim Asy'ari antara lain; interaksi di kelas maupun di luar kelas menggunakan bahasa Arab, tenaga pengajar 80\% lebih berasal dari alumni Timur Tengah yang berkompeten, materi kuliah dirujuk dari kitab-kitab klasik, rata-rata mahasantri memiliki latarbelakang pendidikan yang hampir sama, yaitu pondok pesantren salafiyah, dan adanya beasiswa bagi seluruh Mahasantri. Adapun faktor penghambat antara lain 1) status legal formal yang masih diperjuangkan, sehingga mahasantri harus mengikuti kuliah di IKAHA untuk memperoleh ijazah formal, 2) karena masih harus mengikuti kuliah di IKAHA, maka beban SKS dan mata kuliah yang harus ditempuh mahasantri terlalu berat., dan 3) mengingat di IKAHA memiliki jurusan Tarbiyah dan Syari'ah, maka tidak sedikit mahasantri mengambil jurusan tarbiyah sehingga konsekuensinya dalam menyusun risalah mengikuti jurusan di IKAHA yang tidak linier dengan jurusan di Ma'had 'Aly yang mengembangkan figh-ushul fiqih.
\end{abstract}

Kata Kunci : Pendidikan, Pondok Pesantren, Ma'had 'Aly,

\section{Abstract}

This paper describes the education implementation of Ma'had 'Aly Hasyim in Tebuireng boarding school, Jombang. This study uses a qualitative approach. The results are 1) Ma' had 'Aly Hasyim emphasizes the classics and is oriented to the birth of the next generation of Islam ummah khairu, tafaqquh Fi ad-deen 2) education of Ma'had' Aly Hasyim Asy ' ari is a blend of educational boarding school and salafiyah college experiences 3) the supporting factors in the implementation of education in Ma'had 'Aly Hasyim, among others are interaction inside and outside the classroom using Arabic, the fact that teaching staff are 80\% alumni of the Middle East, the fact that lectures are based upon classic Islamic books, the fact that the students have a similar educational background, and scholarships that are provided for all students. There are inhibiting factors such as 1) claiming formal legal status in advance so Islamic boarding school students may attend college in IKAHA to obtain formal certification, 2) due to the regulations in IKAHA, many credits and courses must be taken by the students and 3) due to the possession of IKAHA in Tarbiyah and Shariah majors, many students prefer choosing tarbiyah which consequently results a non-linier major with Ma'had 'Aly-usul figh in IKAHA while studying and developing figh-ushul figh.

Keywords: Education, boarding school, Ma'had 'Aly,

Naskah diterima 8 April 2013. Revisi pertama, 30 April 2013. Revisi kedua, 20 Mei 2013 dan revisi terahir 15 Juni 2013. 


\section{PENDAHULUAN}

Dunia pondok pesantren salafiyah dewasa ini mulai bergeser seiring dengan regulasi pendidikan nasional, sehingga lambat laun mulai kehilangan indpendensinya. Contoh yang nampak adalah banyaknya berdiri lembaga pendidikan formal yang mengikuti pola pendidikan di bawah Kemendiknas, seperti sekolah umum, wajar dikdas 9 tahun, atau pendidikan tingkat tinggi seperti IKAHA dan STAISA. Akibat dari pendirian lembaga pendidikan tersebut akan melupakan nilainilai dasar pesantren sebagai lembaga Tafaqquh fi ad-Din dan bergeser menjadi lembaga pendidikan umum yang berbasis pada agama. Dengan demikian, mutu lulusan pesantren berkurang dan ijazah lebih penting daripada kualitas keilmuan.

Untuk mengembalikan peran pesantren sebagai lembaga Tafaqquh $f$ i ad-Din dengan mengedepankan kajian kitab-kitab klasik, maka pondok pesantren mendirikan lembaga pendidikan yang menawarkan ketercapaian pada keduanya, yaitu memiliki kemampuan penguasaan kitab klasik akan tetapi juga santri memiliki ijazah formal. Di antara lembaga yang telah didirikan untuk tingkat menengah adalah Madrasah Mu'allimin dan pada tingkat tinggi dikenal dengan istilah Ma'had 'Aly. Berdirinya Mu'allimin dan Ma'had 'Aly di Tebuireng merupakan respon terhadap keinginan berbagai pihak terutama alumni yang merindukan pesantren Tebuireng menghidupkan kembali sistem pendidikan yang dulu pernah ada.

Ma'had 'Aly merupakan lembaga pendidikan formal tingkat tinggi dalam dunia pondok pesantren salafiyah. Hal ini sesuai dengan UU RI Nomor 12 tahun 2012 tentang Perguruan Tinggi pasal 1 ayat 2, bahwa Pendidikan Tinggi adalah jenjang pendidikan setelah pendidikan menengah..." Dan pada Bagian Keenam tentang Pendidikan Keagamaan pasal 30 ayat 2 ditegaskan bahwa pendidikan keagamaan sebagaimana dimaksud pada ayat (1) berbentuk universitas, institut, sekolah tinggi, akademi dan dapat berbentuk Ma'had 'Aly.
Berdasarkan latarbelakang di atas perlu kajian yang lebih mendalam tentang bagaimana posisi Ma'had 'Aly yang diselenggarakan di pondok pesantren, apakah sebagai lembaga yang berkedudukan sama dengan Perguruan Tinggi dan bagaimana implementasi pendidikan yang di selenggarakan oleh Ma'had 'Aly di pesantren tersebut dilihat dari aspek manajemen pengelolaan, penerapan kurikulum, maupun aspek lainnya yang terkait dengan proses pembelajaran.

\section{Rumusan Masalah dan Tujuan Penelitian}

Rumusan masalah yang menjadi fokus kajian dalam penelitian ini adalah

1. Apa orientasi Ma'had 'Aly Hasyim Asy'ari sebagai lembaga pendidikan tinggi yang berada di lingkungan Pondok Pesantren Tebuireng?

2. Bagaimanakah implementasi pengelolaan Ma'had 'Aly Hasyim Asy'ari yang diselenggarakan oleh pondok pesantren Tebuireng, baik dilihat dari manajemen pengelolaan, pelaksanaan pembelajaran, penelitian, dan pengabdian masyarakat?

3. Apa yang menjadi faktor pendukung dan penghambat dalam pengelolaan Ma'had 'Aly Hasyim Asy'ari yang berada di lingkungan pondok pesantren Tebuireng?

Tujuan penelitian ini adalah untuk;

1. Untuk mengetahui orientasi Ma'had 'Aly Hasyim Asy'ari sebagai lembaga pendidikan tinggi yang berada di lingkungan Pondok Pesantren

2. Untuk mengetahui sistem pengelolaan Ma'had 'Aly Hasyim Asy'ari yang diselenggarakan oleh pondok pesantren.

3. Untuk mengetahui faktor pendukung dan penghambat dalam pengelolaan Ma'had 'Aly Hasyim Asy'ari yang berada di lingkungan pondok pesantren. 


\section{Kerangka Pikir}

Kerangka pikir yang dijadikan alur dalam penelitian ini adalah sebagai berikut. kurikulum sangat tergantung pada pimpinan pondok pesantren (kiai). Implementasi atau pelaksanaan kurikulum cukup sederhana

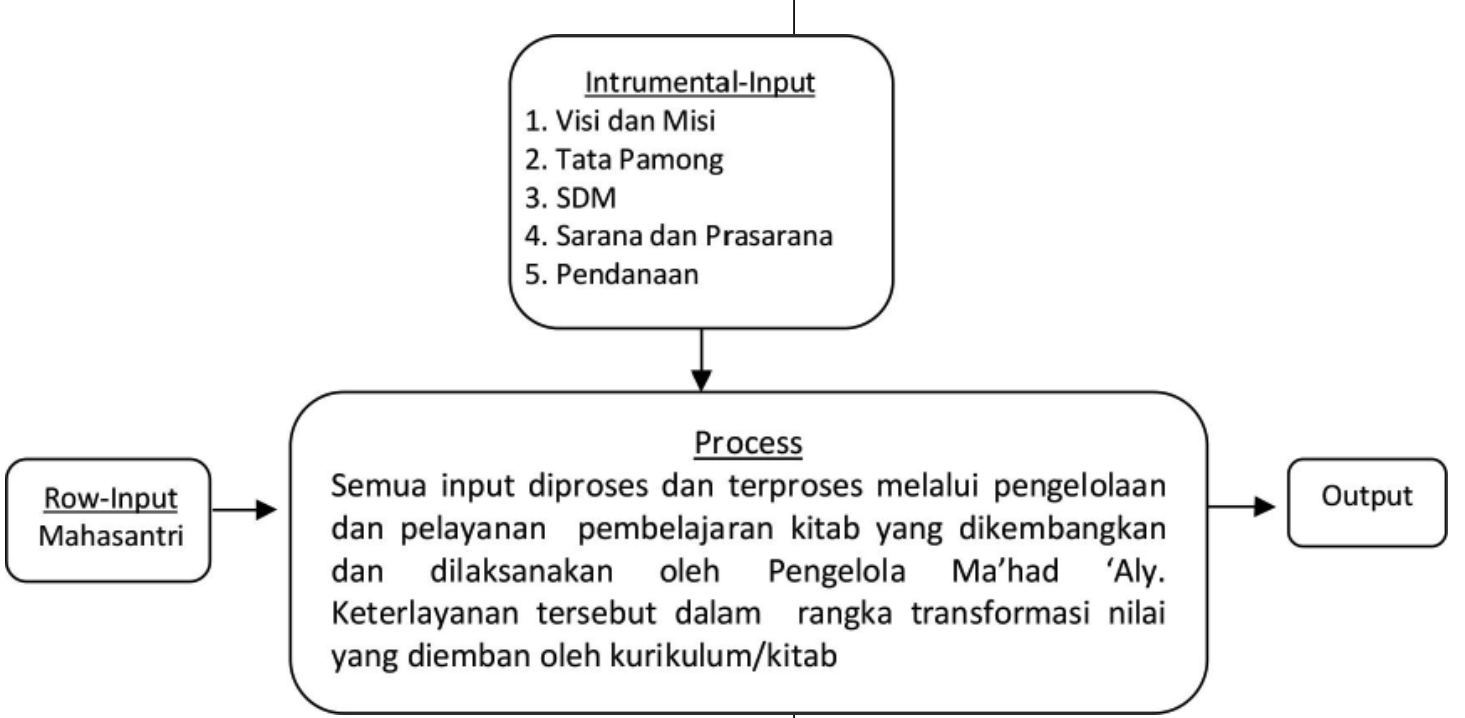

\section{Kerangka Teori}

Secara umum pondok pesantren salafiyah dikenal sebagai lembaga pendidikan yang lebih menekankan pada aspek pengetahuan agama Islam melalui kajian kitab kuning. Sistem pendidikan yang dikembangkan pesantren adalah dari kajian kitab kuning sampai kepada pola pembinaan, bimbingan dan pengembangan untuk mencetak santrisantri yang dapat hidup mandiri. Menurut Ahmad Syafi'i Mufid, bahwa pengembangan lembaga pendidikan oleh pondok pesantren awalnya bersifat tradisional atau salafiyah yang hanya mementingkan pengajian kitab kuning, hal ini dilakukan untuk mempertahankan identitas kulturalnya, yaitu pesantren adalah tafaquh fi ad-din. ${ }^{1}$ Dalam perkembangannya ebih menegaskan lagi, bahwa pesantren lebih mengenalkan kepada tipe madrasi di mana materi ditambah dengan pengetahuan umum. ${ }^{2}$

Kurikulum secara sederhana diidentikan dengan kitab kuning dan untuk menetapkan

${ }^{1}$ A. Syafii Mufid. 1995. Pesantren dan Pengembangan SDM. dalam Jurnal Penamas No. 22 Tahun VII Balai Penelitian Agama dan Masyarakat. Jakarta. h. 43

${ }^{2}$ Karel A. Steenbrink. 1986. Pesantren Madrasah Sekolah: Pendidikan Islam dalam Kurun Modern. LP3ES. Jakarta, h.23 tidak terpengaruh oleh kondisi perkembangan pendidikan secara global, tidak distandarisasi atau tidak memiliki standar yang sama antara satu pondok pesantren dengan pondok pesantren lainnya. Ketidak seragaman dikarenakan pesantren memiliki watak atau karakter yang secara turun menurun terus dikembangkan melalui kajian kitab kuning dari kiai pendahulunya yang mungkin berbeda antar pesantren.

Dalam perkembangan pesantren, menurut Ali Yafie mengalami perubahan, meskipun tidak sedikit pondok pesantren yang tetap mempertahankan sebagaimana awal pendirian, yaitu sebagai lembaga kajian dan dan pengembangan kitab kuning. ${ }^{3}$ Hal ini dikarenakan kitab kuning adalah kepustakaan dan pegangan kiai di pesantren, bahkan antara kiai dengan kitab kuning tidak dapat dipisahkan. Di sinilah menurut Muhammad Tholhah Hasan, bahwa perubahan yang tampak dari pesantren hanyalah baru masuknya sistem sekolah sedangkan sistem pengajaran kitab kuning belum banyak mengalami perubahan,

${ }^{3}$ Alie Yafie. 1989. "Kitab Kuning Produk Peradaban Islam" dalam Pesantren vol.VI. P3M. Jakarta 67 
baik yang menyangkut orientasi keilmuan, metodologi, maupun kurikulumnya. ${ }^{4}$

Perluasan model pondok pesantren ke arah madrasah dengan sendirinya memiliki konsekuensi pada kurikulum yang diimplementasikan. Paling tidak kurikulum yang diimplementasikan mencakup pendidikan dan pengajaran agama sebagai kurikulum yang pokok, pendidikan keterampilan, pendidikan kepramukaan, pendidikan kesehatan dan olah raga dan pendidikan kesenian.

Manajemen menurut para ahli dapat disimpulkan sebagai proses yang mengarah pada sebuah dinamika yang terdiri dari tindakan perencanaan, pengorganisasian, penggiatan dan juga pengawasan serta directing atau pengarahan yang dilakukan untuk menentukan atau mencapai sasaran yang telah ditetapkan melalui pemanfaatan sumber daya manusia dan juga sumber-sumber lainnya sehingga dapat mencapai apa yang telah direncanakan secara bersama.

Perencanaan sebagai satu bentuk kegiatan awal merupakan kegiatan yang terkait dengan penetapan tujuan, standar, penentuan aturan/ prosedur, dan pembuatan format rencana serta ramalan (prediksi) kemungkinan apa yang diperkirakan terjadi. Pengorganisasian adalah bagaimana mengorganisir seluruh kemampuan SDM yang ada dan menetapkan pemberian tugas yang terpisah kepada masing-masing pihak secara professional dan kompeten, membentuk bagian secara proporsional, mendelegasikan atau menetapkan jalur wewenang/tanggungjawab sebagai job discription dan mengatur sistem komunikasi sekaligus sistem kerja, Penggerakan merupakan kegiatan penerapan program yang direncanakan untuk menggerakan kelompok secara efesien dan efektif ke arah pencapaian tujuan yang telah direncanakan, dan Pengawasan merupakan langkah kontroling untuk mengadakan pengendalian atau evaluasi program yang direncanakan awal.

${ }^{4}$ M. Tholhah Hasan. 1989. "Metode Pengajian Kitab Kuning di Pesantren: Tinjauan Ulang. dalam Pesantren vol.IV. Jakarta. h.52
Ma'had 'Aly sebagai lembaga pendidikan tingkat tinggi biasanya lebih ketat dalam manajemen pengelolaannya dibandingkan dengan pondok pesantren yang tidak membuka lembaga pendidikan. Bahkan Kementerian Agama telah merumuskan statuta Ma'had 'Aly sebagaimana yang dilakukan di Perguruan Tinggi. Manajemen yang telah dirumuskan oleh Kementerian Agama adalah dari ketentun umum, aspek visi dan misi Ma'had 'Aly, tujuan dan fungsi Ma'had 'Aly, Organisasi Ma'had 'Aly, kurikulum, sistem pengajaran, tahun akademik, penilaian hasil studi, sampai pada gelar akademik yang diserahkan atau diatur oleh Majlis Ma'had 'Aly sebagai Dewan Nasional.

\section{HASIL DAN PEMBAHASAN}

\section{Dinamika Perkembangan Pondok Pesantren Tebuireng}

Pondok Pesantren Tebuireng Jombang didirikan pada tanggal 26 Rabi'ul Awal $1317 \mathrm{H}$. atau bertepatan dengan tangal 3 Agustus 1899. Setelah berjalan selama 8 tahun mendapat pengakuan resmi oleh pemerintah Belanda, yaitu pada tanggal 6 Pebruari 1906. Lokasi / alamat pondok pesantren berada di Jl. Irian Jaya 10, Tromol Pos 5, Tebuireng, Jombang 61471, Jawa Timur. Pondok Pesantren Tebuireng berada dibawah Yayasan Hasyim Asy'ari Pondok Pesantren Tebuireng.

\section{Profil Ma'had 'Aly Hasyim Asy'ari}

Ma'had 'Aly diresmikan tanggal 6 september 2006 / 12 Sya'ban 1427 H. Proses pendirian atas prakarsa (alm) KH. Muhammad Yusuf Hasyim dan dilestarikan oleh Gus Sholah (KH. Ir. Salahuddin Wahid). Prinsip dilahirkannya adalah melahirkan generasi khoiru ummah. Oleh karena itu penekanan dalam penyelenggaraan adalah studi-studi agama secara mendalam melalui perpaduan sistem pendidikan pondok pesantren dan perguruan tinggi modern. Dari sini diharapkan akan lahir para intelektual muslim yang memiliki akhlaqul karimah dengan kadar intelektual global (A.Mubarok;2011). 
Program Ma'had 'Aly Hasyim Asy'ari adalah Marhalah Alimiyah dengan jurusan Figh wa Ushulihi. Program ini berorientasi untuk mencetak lulusan yang kompeten dalam menganalisa dan menyelesaikan problemproblem fighiyah dengan mendasarkan pada basis tradisi ulama abad klasik. Orientasi inilah yang mendasari rumusan salah satu misinya, yaitu menyelenggarakan dan melaksanakan pengkaderan ahli fiqh dengan membekali dan menanamkan tradisi ilmiyah dan amaliyah alsalaf-al-shalih.

Visi dari pendirian Ma'had 'Aly adalah unggul dalam menguasai tradisi ulama assalaf as-shalihin, baik di bidang ilmiah maupun amaliyah serta lahirnya generasi penerus Islam yang khairu ummah, tafaqquh fi ad-diin. Adapun misinya adalah menyelenggarakan studi agama secara mendalam menyeluruh melalui sistem perpaduan pendidikan pondok pesantren dan perguruan tinggi dan mempersiapkan kaderisasi ahli fiqih yang dapat mewarisi dan mengembangkan tradisi ilmiah dan amaliah sesuai tuntutan zaman.

\section{Sistem Pengelolaan Ma'had Aly}

Sistem tata pamong di Ma'had 'Aly Hasyim Asy'ari telah diatur dalam berbagai peraturan meliputi Statuta Ma'had 'Aly Hasyim Asy'ari, peraturan kepegawaian, peraturan disiplin pegawai, peraturan tata tertib dosen dan mahasantri dan lain sebagainya. Berbagai aturan tersebut berisi struktur organisasi, tugas dan fungsinya yang harus menjadi pedoman kerja maupun perilaku bagi civitas akademika sesuai dengan fungsi dan perannya untu menciptakan system tata pamong yang kredibel, transparan, bertanggungjawab dan adil.

Unsur organisasi Ma'had 'Aly Hasyim Asy'ari terdiri dari Yayasan, Unit Penjaminan Mutu, Pimpinan Ma'had 'Aly, Senat Akademik dan unsur penunjang meliputi: Ka. BAAK, Ka. Perpustakaan, Ka. LPPM dan Ka. LBM (Lembaga Bahtsul Masa'il), Ka. Asrama Mahasantri dan Pembina mahasantri. Ma'had 'Aly Hasyim Asy'ari merupakan Lembaga pendidikan keagamaan tinggi dengan Program Studi setara dengan sarjana (S1) jurusan Fiqih dan Ilmu Fiqih. Kepemimpinan di Ma'had 'Aly Hasyim Asy'ari didasarkan pada statuta, peraturan kepegawaian dan peraturan lainnya yang ditetapkan oleh Mudir dan bersifat partisipatif sehingga pengambilan keputusan dilaksanakan secara demokratis.

Ma'had 'Aly Hasym Asy'ary sebagai lembaga pendidikan formal tingkat tinggi memiliki tata kelola pada setiap program yang direncanakan. Pola pengelolaan dilakukan secara terprogram, terukur dan dapat dievaluasi, yaitu dengan langkah planning, organizaing, staffing, leading, dan terahir dilakukan controlling. Struktur pengelolaan Ma'had 'Aly Hasyim Asy'ari adalah; Yayasan Hasyim Asy'ari, Senat Akademika, Mudir, Wkl Mudir Bid. Akademik, Wkl Mudir Bid. Kemahasiswaan, Ka. BAAK, Ketua Asrama, Ketua LP2M, Ketua Lembaga Tahfidzul Qur'an, Ka. UPT Bahtsul Masail, Ka. UPT Perpustakaan, Staf TU.

Unit penjaminan mutu pendidikan (UPMP) Tebuireng sudah dijadikan sebagai institusi yang penting dan strategis dalamm upaya menjaga dan peningkatan kualitas pendidikan. Secara organisatoris UPMP telah lahir tanggal 9 juli 2007 dengan nama Tim Penjamin Mutu (TPM) dan tanggal 30 Agustus 2007 berganti nama menjadi UPMP dengan harapan mampu membangun kerjasama dengan instansi terkait. Penjaminan mutu mencakup; 1) Standar akademik, 2) Mutu pembelajaran, 3) Mutu dukungan pelayanan kepada mahasantri dan dosen oleh unit layanan akademik dan oleh prasarana administrasi, 3) Tingkat pencapaian mahasantri meliputi hasil penilaian formal, tingkat kepuasan mahasantri terhadap kemajuan studi dan tingkat pencapaian lulusan (alumni) dalam memperoleh pekerjaan beserta penghargaan, 3) Mutu penelitian meliputi mutu proses dan produk akademik, dan 4) Tingkat kepuasan pelanggan.

Mahasantri Ma'had 'Aly Hasyim Asy'ari sejak tahun ajaran baru 2006/2007 berstatus beasiswa dengan rata-rata yang diterima 30 orang. Namun demikian, seiring dengan 
animo yang cukup tinggi dari alumni pondok pesantren dan masyarakat, maka mulai tahun ajaran 2010/2011 menerima 35 Mahasantri.

Jumlah secara keseluruhan Mahasantri adalah sebagai berikut.

\begin{tabular}{|c|c|c|c|c|c|c|}
\hline \multirow{2}{*}{$\begin{array}{l}\text { Tahun } \\
\text { Akademik }\end{array}$} & \multirow{2}{*}{$\begin{array}{c}\text { Daya } \\
\text { tampung }\end{array}$} & \multicolumn{2}{|c|}{$\begin{array}{l}\text { Jumlah Calon } \\
\text { Mahasantri }\end{array}$} & \multicolumn{3}{|c|}{$\begin{array}{l}\text { Presentase Lulusan } \\
\text { Dengan IPK }\end{array}$} \\
\hline & & $\begin{array}{l}\text { Ikut } \\
\text { Seleksi }\end{array}$ & $\begin{array}{l}\text { Lulus } \\
\text { Seleksi }\end{array}$ & $<2,75$ & $<3,50$ & $>3,50$ \\
\hline $2006 / 2007$ & 30 & 65 & 30 & - & - & - \\
\hline $2007 / 2008$ & 30 & 63 & 30 & - & - & - \\
\hline $2008 / 2009$ & 30 & 99 & 30 & - & - & - \\
\hline $2009 / 2010$ & 30 & 98 & 30 & - & - & - \\
\hline 2010/2011 & 35 & 106 & 35 & - & - & - \\
\hline $2011 / 2012$ & 35 & 108 & 35 & - & - & - \\
\hline $2012 / 2013$ & 35 & 105 & 35 & - & - & - \\
\hline
\end{tabular}

Evaluasi kualitas pembelajaran terutama penguasaan bahasa Arab sebenarnya dilakukan dalam setiap proses pembelajaran. Bahkan dalam interaksi keseharian juga dengan menggunakan bahasa Arab sehingga lulusan Ma'had 'Aly memiliki kemampuan berbahasa Arab dengan baik dan mampu meneruskan ke jenjang S.2 dalam negeri maupun luar negeri (Timur Tengah). Evaluasi lulusan dilaksanakan minimal setiap satu tahun sekali pada bulan Desember. Evaluasi ini merupakan rekapitulasi hasil wisuda dalam satu tahun dengan agenda memberikan kuisioner yang akan dikirimkan lewat pos, email atau langsung melalui telephon.

\section{Sumber Daya Manusia}

Untuk memperoleh sumber daya manusia dalam pengelolaan Ma'had 'Aly dilakukan pola rekrutmen dengan menekankan unsur kapabilitas, profesional, dan kompetensi. Contoh rekrutmen SDM pada dosen dengan kualifikasi Pertama, kualifikasi ulama, yakni mereka yang memiliki integritas keulamaan baik dalam hal perilaku, maupun kualitas keilmuan. Dalam hal ini, ijazah tidak menjadi pertimbangan, dan Kedua, kualifikasi intelektual, yakni mereka yang memiliki penguasaan ilmu figh dan memenuhi standar akademik, minimal lulus program strata satu atau telah lulus menempuh pendidikan Ma'had 'Aly Hasyim Asy'ari.

Dilihat dari aspek kelompok tenaga pengajar, yaitu Al-Muhādhirūn, Al-Mudarrisūn, dan Al-musyrifūn adalah sebagai berikut.

1. Al-Muhādhirūn, yaitu beberapa tenaga pengajaryangsecaratemporalmemberikan kuliah umum dengan tema-tema sentral yang meliputi Masail Fiqhiyah, Ushul Fiqh, Sosial Politik, Tasawwuf dan Filsafat.

2. Al-Mudarrisūn, yaitu beberapa tenaga pengajar yang secara rutin memberikan kuliah dengan jadwal dan mata kuliah yang telah ditentukan.

3. Al-musyrifün, yaitu beberapa tenaga pengajar yang bertugas sebagai pendamping harian, dengan mengawasi dan membimbing santri secara intensif.

\section{Implementasi Pendidikan di Ma'had 'Aly}

Pendidikan di Ma'had 'Aly Hasyim Asy'ari tidak berbeda dengan pelaksanaan pendidikan pada perguruan tinggi padaumumnyaterutama pendidikan tinggi keagamaan, yaitu tidak lepas dari Tridharma Perguruan Tinggi. Dalam UU nomor 12 tahun 2012 pada pasal 1 ayat 9 dijelaskan bahwa Tridharma Perguruan Tinggi adalah kewajiban Perguruan Tinggi untuk menyelenggarakan pendidikan, penelitian, dan pengabdian kepada masyarakat.

Struktur kurikulum Ma'had 'Aly Marhalah Alimiyah terbagi menjadi lima komponen mata kuliah. Susunan struktur kurikulum sebagaimana terlampir. Adapun lima komponen mata kuliah adalah Mata Kuliah Dasar (Kompetensi Dasar), Mata Kuliah Konsentrasi (Kompetensi Utama), Mata Kuliah Pendukung (Kompetensi Pendukung), Mata Kuliah Keterampilan, dan Penulisan Skripsi

Beban studi mahasantri yang harus ditempuh atau diselesaikan pada tingkat Marhalah Alimiyah atau S.1. sama dengan beban studi yang harus ditempuh pada perguruan 
tinggi pada umumnya, yaitu secara keseluruhan berjumlah 144 SKS ditambah dengan KKN dan penyusunan tugas akhir atau risalah. Beban studi dalam bentuk SKS ini terbagi menjadi 3 jenis mata kuliah, yaitu mata kuliah umum, mata kuliah wajib, dan mata kuliah tambahan.

\section{Pengembangan Penelitian.}

Pengembangan penelitian dilakukan antara pihak rektorat, dosen dengan Mahasantri ketika mengadakan Kuliah Kerja Nyata (KKN). Penelitian tersebut dengan menggunakan pendekatan PAR (Partsipation Action Research). Pengembangan penelitian juga dilakukan oleh Mahasantri pada semester akhir, yaitu dalam penyusunan risalah atau skripsi. Meskipun dalam penyusunan risalah ini masih terbagi dalam beberapa tema sesuai dengan jurusan yang diambil mahasantri di IKAHA. Menurut Nurhanan, bahwa mulai dua tahun ke depan mahasantri mulai fokus dalam penyusunan risalah, yaitu terkait Figh - Ushul Fiqh sebagai program yang ditetapkan Ma'had ‘Aly Hasyim Asy'ari.

\section{Pengabdian Masyarakat.}

Dalam konteks pondok pesantren, menurut Ir. KH. Salahuddin Wahid masih perlu ditumbuhkan kembali sumbangsih pesantren dalam pendidikan dan perlu diperjuangkan bersama dari berbagai pesantren terkait dengan prestasi dan kiprahnya di masyarakat melalui berbagai program. Program ini berupa kegiatan pelayanan/pengabdian kepada masyarakat yang sesuai dengan bidang keilmuwan di Ma'had 'Aly. Pelayanan ini tidak hanya dilakukan oleh dosen, akan tetapi juga dilakukan oleh Mahasantri dengan bimbingan dari dosen.

Salah satu kegiatan pelayanan/ engabdian kepada masyarakat yang melibatkan mahasantri adalah dengan mengadakan bimbingan kepada masyarakat di berbagai tempat yang membutuhkan. Kegiatan ini melibatkan mahasantri yang sudah senior di desa-desa yang memerlukan. Pelaksanaan kegiatan hampir sama dengan model KKN hanya saja formatnya berbeda.

\section{ANALISIS DATA}

Yayasan Hasyim Asy'ari Tebuireng di bawah kepimpinan Ir. KH. Salahuddin Wahid lebih mengedepankan bagaimana mengembalikan "kebesaran" pondok pesantren Tebuireng dan bagaimana pondok pesantren memiliki generasi yang memiliki kemampuan dalam penguasaan kitab kuning atau kitab klasik karya ulama salaf. Namun demikian, sesuai dengan perkembangan zaman, maka dalam manajemen diperlukan langkah-langkah strategis agar semua program yang dirumuskan bersama pengelola dapat tercapai.

Model yang dikembangkan oleh Yayasan dan Pengelola Ma'had 'Aly adalah menganut sistem tata pamong sebagaimana di perguruan tinggi, sehingga seluruh perangkat telah diatur dalam berbagai peraturan, baik berkaitan dengan Statuta Ma'had 'Aly Hasyim Asy'ari, peraturan kepegawaian, peraturan disiplin pegawai, peraturan tata tertib dosen dan mahasantri dan lain sebagainya. Sistem ini telah berjalan sesuai dengan mekanisme yang ada dan dilakukan konsolidasi internal dengan melibatkan seluruh elemen yang terkait.

Keberhasilan Ma'had 'Aly Hasyim Asy'ari sebagai lembaga pendidikan tingkat tinggi di pondok pesantren tidak lepas dari model kepemimpinan yang diterapkan, yaitu tetap berpegang pada tradisi pondok pesantren salafiyah, akan tetapi tetap mengembangkan manajemen modern. Apalagi konsistensi dalam pengelolaan yang mendasarkan pada statuta, peraturan kepegawaian dan peraturan lainnya yang ditetapkan oleh Mudir baik melalui rapat pimpinan maupun rapat dengan dosen menjadikan seluruh civitas academica Ma'had 'Aly memiliki kebersamaan yang kuat dalam membangun Ma'had 'Aly Hasyim Asy'ari ke depan.

Model kepemimpinan yang bersifat partisipatif dan demokratis terutama dalam pengambilan keputusan mengarahkan 
pada sikap semua aspirasi yang ada bisa mendapatkan apresiasi untuk pelaksanaannya meskipun harus disesuaikan dengan skala prioritas tahunan dari Ma'had 'Aly Hasyim Asy'ari. Inilah "kekuatan" kepemimpinan yang dikelola secara bersama-sama dan memiliki visi dan misi yang sama pula.

\section{Kebijakan Akademik}

Proses untuk menentukan sebuah kebijakan dalam akademik merupakan proses yang terus berjalan sesuai dengan hasil evaluasi yang dilakukan dalam setiap semester dan setiap tahun. Seluruh kebijakan akademik terutama untuk menentukan kurikulum dan beban SKS yang diterapkan pada Mahasantri juga terus mengalami dinamika seiring dengan tuntutan pengembangan keilmuan dan tuntutan profesionalitas dan kompetensi.

Beberapa kebijakan akdemik yang telah dilakukan antara lain adalah pengembangan kurikulum yang mengarah pada kompetensi lulusan, yaitu lebih pada mata kuliah yang mendukung pada visi dan misi Ma'had 'Aly Hasyim Asy'ari dengan program fiqih - ushul fiqh. Bahkan penyusunan risalah sebagai tugas akhir mahasantri diarahkan dengan tematema yang terkait dengan ilmu-ilmu syariah.

Beban SKS pada awalnya di atas 190 SKS, akan tetapi dalam perkembangannya menyesuaikan dengan tuntutan yang ada di Perguruan Tinggi secara umum, yaitu antara 144 - 160 SKS. Beban SKS ini sudah termasuk KKN yang berjumlah 4 SKS dan KKN ini menggunakan kebijakan rektorat dengan melaksanakan penelitian yang bersifat action research atau PAR (Participation Action Research). Kebijakan akademik lainnya adalah penerimaan mahasantri yang pada awalnya hanya 30 orang setiap tahunnya, akan tetapi karena animonya terlalu tinggi, maka mulai tahun pelajaran 2010/2011 penerimaan Mahasantri baru berjumlah 35 orang.

Kegiatan ekstra universiter yang dilakukan oleh Ma'had 'Aly dapat berkembang dengan baik. Dukungan yang tinggi dari pihak rektorat menjadikan kegiatan atau lembaga otonom kampus, seperti Resimen Mahasiswa (Menwa), Pramuka, dan aktivitas di Badan Eksekutiv Mahasiswa memperoleh prestasi tersendiri. Bahkan pada tingkatan Badan Eksekutif Mahasiswa (BEM) tingkat antar Perguruan Tinggi se Kabupaten Jombang berhasil menduduki jabatan bergengsi, yaitu sebagai Sekretaris Umum BEM se Kabupaten Jombang yang berjumlah 15 Perguruan Tinggi.

Kebijakan akademik yang diambil Ma'had 'Aly dalam berbagai kegiatan maupun pada penentuan kurikulum merupakan kebijakan otoritas perguruan tinggi yang adaptif dengan perkembangan dan tuntutan keilmuan. Menurut Nurhanan Lc. MHI. Bahwa, Ma'had 'Aly tetap memiliki karakter tersendiri sebagai lembaga pendidikan tinggi yang berada di pondok pesantren salafiyah, akan tetapi interaksi dengan lembaga Perguruan Tinggi yang ada di Jombang dalam berbagai event masih mampu untuk bersaing.

Melalui berbagai kebijakan akademik yang dibangun menjadikan Ma'had 'Aly sebagai lembaga pendidikan tinggi di pondok pesantren salafiyah memiliki bargaining position di tengah-tengah perguruan tinggi pada umumnya. Penentuan kebijakan yang bersifat akademis oleh Rektorat dan pengelola menghasilkan peningkatan kualitas akademis mahasantri tidak hanya pada aspek kognitif atau penguasaan keilmuan, akan tetapi juga membangun mahasantri sebagai agen terhadap perubahan sosial (Social Agent of Change). Lebih jauh Ma'had 'Aly Hasyim Asy'ari membangun mahasantri menjadi generasi yang diharapkan, yaitu cerdas, visible, jujur dan berani.

\section{Sistem Penjaminan Mutu Pendidikan}

Model penjaminan mutu pendidikan yang dilakukan oleh Ma'had 'Aly Hasyim Asy'ari masih dilakukan secara integral dengan pondok pesantren. Lembaga penjaminan mutu yang berada di bawah kendali Unit penjaminan mutu pendidikan (UPMP) Tebuireng merupakan institusi yang penting dan strategis dalam 
upaya menjaga dan peningkatan kualitas pendidikan.

Tuntutan penjaminan mutu pendidikan yang berpusat pada lembaga penyelenggara pendidikan secara spesifik untuk kegiatan akademik sudah mulai ada perkembangan dengan merumuskan standar akademik. Standar akademik ini untuk mengukur kesesuaian tingkat mutu kuliah dengan tujuannya, pembaharuan kurikulum dan evaluasi pencapaian tujuan kurikulum. Di samping itu, standar akademik untuk melihat mutu pembelajaran dari aspek motivasi dosen, daya tarik dan relevansi mata kuliah, keefektifan metode pembelajaran, manajemen perkuliahan, tanggapan mahasantri, kemampuan mata kuliah membantu pengembangan pengetahuan mahasantri, pemahaman dan kompetensi yang diperlukan sesuai tingkat yang dibutuhkan.

Pada tataran aplikatif, standar mutu pendidikan yang dilakukan UPMP sebenarnya mulai mengedepankan kompetensi dan profesionalitas. Oleh karena itu, keterlibatan dalam penyusunan mata kuliah dan kurikulum akademik dilakukan oleh pelaksana pendidikan pada tingkat Ma'had 'Aly Hasyim Asy'ari dengan mekanisme kerja sebagaimana dilakukan UPMP selama ini, yaitu dengan prinsip koordinasi, integrasi, dan sinkronisasi.

Model penjaminan mutu yang mulai mengedepankan profesionalitas dan kompetensi sudah selayaknya menjadi perhatian Ma'had 'Aly Hasyim Asy'ari, mengingat keberadaan Ma'had 'Aly Hasyim Asy'ari sudah mulai "dilirik" bukan saja oleh alumni dari pondok pesantren Tebuireng, akan tetapi dari berbagai pondok pesantren salafiyah di jawa dan luar jawa. Melalui penjaminan mutu pendidikan yang telah terwadahi dalam lembaga khusus UPMP akan menjadikan Ma'had 'Aly lebih terkonsentrasi menjaga kualitas alumni yang mencetak generasi unggul dalam menguasai tradisi ulama assalaf as-shalihin, baik di bidang ilmiah maupun amaliyah serta lahirnya generasi penerus Islam yang khairu ummah, tafaqquh fi ad-diin.

\section{Implementasi Pendidikan Ma'had 'Aly HasyimAsy'ari}

Ma'had 'Aly Hasyim Asy'ari adalah lembaga pendidikan tinggi keagamaan yang dijamin dalam UU RI No. 12 tahun 2012 tentang Pendidikan Tinggi pasal 30. Oleh karena itu, implementasi pendidikan yang dikembangkan tidak berbeda dengan pelaksanaan pendidikan pada perguruan tinggi pada umumnya terutama pendidikan tinggi keagamaan, yaitu menerapkan Tridharma Perguruan Tinggi sebagai landasan utama dalam melaksanakan pendidikan.

Pada tataran aplikatif, implementasi pendidikan di Ma'had 'Aly Hasyim Asy'ari dapat dilihat pada ketiga aspek dalam tridharma perguruan tinggi tersebut. Pertama, dalam aspek penyelenggaraan pendidikan dilihat dari tenaga pengajar sebagian besar merupakan dosen yang mengajar di Perguruan Tinggi, seperti IAIN dan alumni bergelar Master (S.2) dan Doktor (S.3) dan dilihat dari aspek mata kuliah atau kurikulum merupakan kurikulum yang telah didesain sesuai dengan beban yang diberikan kepada mahasantri dengan sistem SKS (Sistem Kredit Semester). Jumlah total SKS yang harus ditempuh mahasantri adalah 144 SKS dalam waktu paling cepat 4 tahun dan proses belajar mengajar disampaikan dengan bahasa Arab dan bahasa Inggris.

Kedua, Pengembangan aspek penelitian selalu ditekankan terutama untuk tenaga pendidik /dosen. Akan tetapi dalam perkembangannya ternyata Mahasantri tertarik untuk mengadakan penelitian dan mengebangkan karya ilmiah dalam bentuk kajian buku maupun kajian kajian kritis terhadap fenomena social keagamaan. Karya tersebut berupa tulisan dalamjurnal Tebuireng, Mahamedia, dan telah menjadi buku popular.

Ketiga, pengabdian masyarakat bagi pondok pesantren adalah sesuatu yang sangat akrab. Dalam konteks pondok pesantren, menurut Ir. KH. Salahuddin Wahid masih perlu ditumbuhkan kembali sumbangsih pesantren dalam pendidikan dan perlu diperjuangkan 
bersama dari berbagai pesantren terkait dengan prestasi dan kiprahnya di masyarakat.

\section{Kurikulum Pembelajaran dan Suasana Akademik}

Rancangan kurikulum Ma'had 'Aly Hasyim Asy'ari pada prinsipnya telah dirancanng sesuai standar pelayanan penjaminan mutu pembelajaran. Standar tersebut didasarkan pada relevansi materi dengan tujuan, cakupan dan kedalaman materi, serta pengorganisasian yang dapat diterapkan dalam berbagai situasi dan kondisi. Penerapan kurikulum pembelajaran yang diwujudkan dalam bentuk mata kuliah dengan mempertimbangkan aspek kompetensi lulusan, kompetensi pendukung lulusan, dan kompetensi lainnya sebagai pilihan.

Kompetensi lulusan mempertimbangkan bagaimana kurikulum tersebut mampu menggali serta mengembangkan nilai-nilai khasanah keislaman, mampu memecahkan masalah-masalah keagamaan secara tepat sesuai dengan perkembangan zaman, dan mampu mengaktualisasikan sikap shaleh (Akhlaq al-Karimah) dan kepakaran (Ulum an-Nafi'ah). Kompetensi pendukung lulusan merupakan kompetensi penunjang setelah mahasantri selesai mampu menerjemahkan dan berkomunikasi dalam bahasa Arab dan Inggris secara baik dan lancar, memiliki kemampuan komunikasi (Communication skill) yang baik, memiliki karakter kepemimpinan (Leadership), mampu dalam penguasaan computer, memiliki kemampuan untuk bekerjasama (Teamwork), memiliki pola pikir yang terarah, dan kreatif dan inovatif. Adapun untuk menambah talenta mahasantri setelah lulus sesuai karakteristik yang dimiliki latarbelakang berbeda dan memiliki keahlian tertentu diberikan kurikulum tambahan sesuai dengan pilihan mahasantri.

Kurikulum inti, kurikulum penunjang maupun kurikulum tambahan secara komunal dirumuskan untuk masa studi yang harus ditempuh atau diselesaikan pada tingkat Marhalah Alimiyah atau S.1. Secara keseluruhan beban studi yang harus ditempuh berjumlah 144 SKS ditambah dengan KKN dan penyusunan tugas akhir atau risalah. Beban studi dalam bentuk SKS ini terbagi menjadi 3 jenis mata kuliah, yaitu mata kuliah umum 50 SKS, mata kuliah wajib 56 SKS, dan mata kuliah tambahan 38 SKS.

Suasana pembelajaran sangat kental dengan iklim akademis ini dipengaruhuhi oleh interaksi yang semuanya dengan menggunakan bahasa Arab. Hal ini ditambah dengan posisi kampus yang mengedepankan pengembangan keilmuan melalui penempatan perpustakaan di lantai 1 depan kantor dan ruang kuliah yang jauh dari kebisingan. Kondisi interaksi antar mahasantri maupun dengan dosen dan tenaga kependidikan lainnya merupakan kondisi yang menciptakan iklim di kampus sebagai iklim akademis. Apalagi ketika proses bimbingan terhadap mahasantri dalam penyusunan risalah dilakukan di kampus, maka suasana akademis akan semakin terdukung.

\section{Bentuk-bentuk Pengembangan Penelitian}

Sebagaimana di jelaskan di atas, bahwa pengembangan penelitian dilakukan dengan pendekatankajianliteraturdankajianlapangan. Bentuk penelitian yang dikembangkan masih disesuaikan dengan penelitian yang dikembangkan di IKAHA, baik dalam rangka penelitian murni maupun penelitian untuk menyusun risalah dan pendekatan penelitian yang digunakan adalah pendekatan kuantitatif dan kualitatif. Penelitian untuk penyusunan risalah disesuaikan dengan program/jurusan yang diambil mahasantri di IKAHA, sehingga tidak sedikit yang mengambil spesialisasi pendidikan dengan bentuk pengembangan penelitian pada aspek pendidikan.

Bentuk penelitian yang telah dilakukan secara bersama-sama / Tim adalah apda saat penelitian aksi atau PAR. Dalam penelitian ini Ma'had 'Aly mencoba untuk menerapkan bentuk pengembangan penelitian PAR yang sangat jarang atau tidak pernah dilakukan oleh para dosen maupun mahasantri dalam 
menyusun tugas akhir. Namun demikian, dalam perkembangannya belum dilakukan penelitian dengan menggunakan pendekatan tersebut.

Model atau bentuk pengembangan penelitian yang telah dilakukan selama ini sebenarnya memberikan kontribusi mahasantri untuk gemar dalam penelitian. Akan tetpai perlu diarahkan pada penelitian yang bersifat menunjang pada kompetensi mahasantri selama memgkuti program di Ma'had 'Aly bukan mengacu pada ketika mahasantri menjadi mahasiswa IKAHA. Hal ini sebenarnya telah ditunjukan oleh mahasantri senior seperti A. Mubarok Yasin, dkk yang meneliti dan menulis tentang profil, baik profil pondok pesantren maupun profil tokoh secara individu.

\section{Bentuk-bentuk Pengabdian Masyarakat dan Kerjasama}

Ma'had 'Aly Hasyim Asy'ari Tebuireng merupakan lembaga pendidikan tingkat tinggi di pondok pesantren dan beridiri pada tahun 2006.Lembagainibelummewisudamahasanntri untuk menjadi sarjana S.1 sehingga bentukbentuk pengabdian yang dilakukan belum nampak. Sumbangsih Ma'had 'Aly sementara ini dilakukan secara personal, yaitu sebagai dosen maupun sebagai mahasantri yang aktif dalam kegiatan kemasyarakatan sesuai dengan kompetensinya.

Di antara bentuk pengabdian yang dilakukan oleh dosen maupun mahasantri adalah pada lembaga pendidikan sebagai tenaga pengajar, masjid dan mushalla sebagai tenaga penyuluh keagamaan, dan di rumah sebagai konsultan masalah keagamaan (tempat bertanya anggota masyarakat terutama masalah keagamaan).

Untuk menyempurnakan pengabdian masyarakat akan dilakukan masa pengabdian bagimahasantri Ma'had 'Aly selama satuatau dua tahun dikirim ke tengah-tengah masyarakat yang membutuhkan. Pengiriman mahasantri ini dilakukan sebelum mendapatkan ijazah formal. Program seperti ini akan menjadi daya tarik tersendiri dan menjadi karakter tersendiri bagi lembaga pendidikan tinggi dalam mengimplementasikan Tridharma Perguruan Tinggi.

\section{Faktor Pendukung dan Penghambat dalam Implementasi Pendidikan}

\section{Faktor Pendukung Implementasi Pendidikan}

Implementasi Pendidikan di Ma'had 'Aly Hasyim Asy'ari Tebuireng telah berjalan sebagaimana perguruan tinggi keagamaan pada umumnya. Dilihat dari aspek kurikulum pembelajaran telah tersusun sesuai dengan program yang dikembangkan yaitu fiqih ushul fiqh dan telah tersusun beban kurikulum yang harus ditempuh mahasantri dengan jumlah 144 SKS.

Pada aspek proses pengajaran dilakukan dengan bahasa Arab sebagai bahasa pengantar maupun bahasa diskusi dalam kelas dan di luar kelas pada mata kuliah selain bahasa Inggris, bahasa Indonesia, dan ilmu falak. Pada aspek metode pengajaran telah menggunakan berbagai metode sesuai dengan kebutuhan, yaitu ceramah, diskusi dan penyampaian makalah oleh mahasantri. Kekayaan yang sangat luar biasa dalam pengajaran di Ma'had 'Aly adalah seluruh interaksi dengan menggunakan bahasa Arab. Di Ma'had 'Aly tidak hanya mampu menguasai bahasa Arab dengan baik secara teoritik, akan tetapi secara praktis juga menguasai apalagi tenaga pengajarnya berasal dari Timur Tengah dan lebih dari $80 \%$ lulusan Timur Tengah.

Pengajaran disampaikan oleh dosendosen yang memiliki kompetensi cukup tinggi, sehingga mahasantri tidak kesulitan untuk mendiskusikan berbagai makalah individu maupun kelompok. Kompetensi yang dimiliki oleh oleh dosesn tidak hanya kompetensi personal, professional, dan kompetensi social, akan tetapi para dosen juga memiliki kompetensi pedagogik sebagai kemampuan dalam mengelola pengajaran. 
Materi kuliah yang diambil atau dirujuk dari kitab-kitab klasik sangat mendukung para mahasantri untuk mengkaji lebih mendalam. Bahkan tidak sedikit mata kuliah yang menjadi tantangan untuk menguasainya, seperti mata kuliah takhrij Hadits. Menurut Mansyur, bahwa selama belajar di pesantren menerima saja hadits yang dibaca atau disampaikan oleh Kiai, akan tetapi setelah menerima mata kuliah takhrij hadits menjadi ada kelebihan tersendiri dan pada saat menerima mata kuliah ilmu falak bisa langsung dengan ilmu-ilmu modern.

Faktor pendukung lainnya adalah dari aspek mahasantri rata-rata cukup pandai, memiliki latarbelakang pendidikan yang hampir sama, yaitu pondok pesantren salafiyah dan sangat kondusif dalam menerima materi mata kuliah. Mahasantri yang hanya berjumlah 30 orang dalam satu angkatan dan hasil seleksi yang sangat ketat menjadikan interkasi pembelajaran tidak mengalami kesulitan dan bahkan saling mendukung dalam peningkatan kualitas pembelajaran dan kualitas pengembangan organisasi intern dan ekstern kampus.

Keberadaan gedung permanen dan beberapa fasilitas pembelajaran yang ditunjang dengan perpustakaan yang cukup banyak untuk kajian kitab kuning merupakan factor pendukung tersendiri. Fasilitas pembelajaran ini cukup representatif bagi para mahasantri yang berada dalam satu asrama dan satu pondok.

Hal yang paling mendukung bagi para mahasantri dalam menempuh kuliah di Ma'had 'Aly Hasyim Asy'ari adalah adanya beasiswa. Seluruh Mahasantri dibebaskan dari masalaha keuangan, baik uang SPP maupun uang kegiatan lainnya. Mahasantri dapat dikatakan di"manjakan" sehingga termotivasi untuk lebih serius mengikuti kuliah. Bagi mahasantri tidak ada alasan untuk tidak aktif dalam seluruh aktivitas academica, karena seluruh pembiayaan telah ditanggung oleh Yayasan.

\section{Faktor Penghambat Implementasi Pendidikan}

Faktor penghambat yang paling penting adalah belum adanya status yang jelas Status Ma'had 'Aly Hasyim Asy'ari dari pemerintah. Menurut Nurhanan. Status legal formal Ma'had 'Aly menjadikan sebuah kendala yang sampai sekarang masih harus diperjuangkan. Menurutnya, bahwa apabila status Ma'had 'Aly masih mengambang dan tidak ada kejelasan akan berakibat pada beban mahasantri yang terlalu berat karena harus mencari legalitas formal pada perguruan tinggi lain (IKAHA) dan apabila status telah jelas sebagai lembaga pendidikan keagamaan tingkat tinggi sebagaimana diatur dalam UU RI tentang Pendidikan Tinggi bagian keenam pasal 30, maka mahasantri tidak lagi harus mengikuti kuliah di IKAHA.

Adanya double kuliah mahasantri, yaitu di Ma'had 'Aly dan di IKAHA menjadikan santri terbebani dua kurikulum dan juga terbebani biaya kuliah, padahal di Ma'had 'Aly gratis dan dapat beasiswa. Pembebanan pada aspek kurikulum dan biaya paling tidak menjadikan Mahasantri harus berfikir keberlangsungan pada kedua perguruan tinggi (Ma'had 'Aly) dan IKAHA dapat berjalan efektif dan efisien serta selesai sesuai dengan target.

\section{PENUTUP}

\section{Simpulan}

1. Orientasi Ma'had 'Aly Hasyim Asy'ari sebagai lembaga pendidikan tinggi yang berada di lingkungan Pondok pesantren lebih menekankan padakitab-kitabklasiksebagai rujukan utamanya dan mengedepankan orientasi pada lahirnya generasi penerus Islam yang khairu ummah, tafaqquh fi addiin.

2. Model penyelenggaraan pendidikan Ma'had 'Aly Hasyim Asy'ari dengan sistem perpaduan pendidikan pondok pesantren dan perguruan tinggi. Perpaduan ini tidak hanya pada kurikulum yang membuka mata kuliah umum akan tetapi juga dalam manajemen pengelolaan dengan 
menggunakan manajemen modern, yaitu Planning, Organising, Actuiting, Controlling, staffing dan leading.

3. Faktor pendukung dalam implementasi Pendidikan di Ma'had 'Aly Hasyim Asy'ari Tebuireng antara lain ;

a. Seluruh interaksi di kelas maupun di luar kelas menggunakan bahasa Arab dan tenaga pengajar $80 \%$ lebih berasal dari alumni Timur Tengah.

b. Pengajaran disampaikan oleh dosendosen yang memiliki kompetensi cukup tinggi, baik kompetensi personal, professional, maupun kompetensi social dan kompetensi pedagogik.

c. Materi kuliah dirujuk dari kitab-kitab klasik

d. Rata-rata mahasantri sebagai input cukup pandai, memiliki latarbelakang pendidikan yang hampir sama, yaitu pondok pesantren salafiyah dan sangat kondusif dalam menerima materi mata kuliah.

e. Keberadaan gedung permanen dan beberapa fasilitas pembelajaran.

f. Adanya beasiswa bagi seluruh Mahasantri.

g. Adanya motivasi yang cukup kuat dari mahasantri untuk mengikuti perkuliahan di Ma'had 'Aly Hasyim Asy'ari.

4. Faktor penghambat dalam implementasi pendidikan di Ma'had 'Aly adalah;

a. Status legal formal yang masih diperjuangkan, sehingga mahasantri harus mengikuti kuliah di IKAHA untuk memperoleh ijazah formal.

b. .Karena masih harus mengikuti kuliah di IKAHA, maka beban SKS dan mata kuliah yang harus ditempuh mahasantri terlalu berat. Konsekuensi dari status menjadi mahasiswa IKAHA adalah harus mengikuti kuliah di IKAHA dan harus mengeluarkan biaya. c. mengingat di IKAHA memiliki jurusan Tarbiyah dan Syari'ah, maka tidak sedikit mahasantri mengambil jurusan tarbiyah sehingga konsekuensinya dalam menyusun risalah mengikuti jurusan di IKAHA yang tidak linier dengan jurusan di Ma'had 'Aly yang mengembangkan fiqh-ushul fiqih.

\section{SUMBER BACAAN}

Abdurrahman Wahid. Menggerakan Tradisi; Esai-esai Pesantren. LKiS. Yogjakarta. 2007.

Dudung Abdurrahman, dkk. 2004. Membangun Konsep Pendidikan Ma'had 'Aly dalam Istiqro' Jurnal Penelitian Direktorat Perguruan Tinggi Islam Vol. 03 Nomor 01. Jakarta.

Keputusan Dirjen Pembinaan Kelembagaan Agama Islam No. E/179/2001 tentang Pokok-pokok Pedoman Penyelenggaraan Ma'had 'Aly.

Keputusan Menteri Agama R.I. Nomor 284 tahun 2001 tentang Ma'had 'Aly

Majalah Tebuireng;Media Pendidikan dan Keagamaan. Edisi 15/Mei-Juni 2011. Jombang.2011

Marzuki Wahid, Ma'had 'Aly: Nestapa Tradisionalisme dan Tradisi Akademik yang Hilang dalam Istiqro' Jurnal Penelitian Direktorat Perguruan Tinggi Islam Vol. 04 Nomor 01. Jakarta. 2005.

Mubarok Yasin, dkk.,Profil Pesantren Tebuireng. Pustaka Tebuireng. Jombang, 2011.

UU Republik Indonesia Nomor 12 Tahun 2012 tentang Perguruan Tinggi. 